\title{
Calcium-sensing receptor (CaSR) promotes development of bone metastasis in renal cell carcinoma
}

\author{
Sebastian Frees ${ }^{1,2, *}$, Ines Breuksch ${ }^{3, *}$, Tobias Haber ${ }^{2}$, Heide-Katharina Bauer ${ }^{3}$, \\ Claudia Chavez-Munoz ${ }^{1}$, Peter Raven ${ }^{1}$, Igor Moskalev ${ }^{1}$, Ninadh D ' Costa ${ }^{1}$, Zheng \\ Tan $^{1}$, Mads Daugaard ${ }^{1}$, Joachim W. Thüroff' ${ }^{2,4}$, Axel Haferkamp², Dirk Prawitt ${ }^{5}$, \\ Alan So ${ }^{1}$ and Walburgis Brenner ${ }^{2,3}$ \\ ${ }^{1}$ Department of Urologic Sciences, University of British Columbia, Vancouver Prostate Centre, British Columbia, Canada \\ ${ }^{2}$ Department of Urology, Johannes Gutenberg University Medical Center, Mainz, Germany \\ ${ }^{3}$ Department of Gynecology, Johannes Gutenberg University Medical Center, Mainz, Germany \\ ${ }^{4}$ Current address: Department of Urology, University Clinic Mannheim, Mannheim, Germany \\ ${ }^{5}$ Department of Pediatrics, Johannes Gutenberg University Medical Center, Mainz, Germany \\ "These authors contributed equally to this work \\ Correspondence to: Sebastian Frees, email: sebastian.frees@unimedizin-mainz.de \\ Keywords: renal cell carcinoma; calcium-sensing receptor; bone metastases, metastasis; kidney cancer \\ Received: December 21, 2017 Accepted: February 25, 2018 Epub: March 02, 2018 Published: March 20, 2018 \\ Copyright: Frees et al. This is an open-access article distributed under the terms of the Creative Commons Attribution License 3.0 \\ (CC BY 3.0), which permits unrestricted use, distribution, and reproduction in any medium, provided the original author and source \\ are credited.
}

\section{ABSTRACT}

Bone metastasis is an important prognostic factor in renal cell carcinoma (RCC). The calcium-sensing receptor (CaSR) has been associated with bone metastasis in several different malignancies. We analyzed the impact of CaSR in bone metastasis in RCC in vitro and in vivo. The RCC cell line 786-0 was stably transfected with the CaSR gene and treated with calcium alone or in combination with the CaSR antagonist NPS2143. Afterwards migration, adhesion, proliferation and prominent signaling molecules were analyzed. Calcium treated CaSR-transfected 768-0 cells showed an increased adhesion to endothelial cells and the extracellular matrix components fibronectin and collagen I, but not to collagen IV. The chemotactic cell migration and proliferation was also induced by calcium. The activity of SHC, AKT, ERK, P90RSK and JNK were enhanced after calcium treatment of CaSR-transfected cells. These effects were abolished by NPS2143. Development of bone metastasis was evaluated in vivo in a mouse model. Intracardiac injection of CaSR-transfected 768-O cells showed an increased rate of bone metastasis. The results indicate CaSR as an important component in the mechanism of bone metastasis in RCC. Therefore, targeting CaSR might be beneficial in patients with bone metastatic RCC with a high CaSR expression.

\section{INTRODUCTION}

Renal cell carcinoma (RCC) is among the ten most common cancer sites in men and women. Current estimates show that 62700 new cases will occur in the United States in 2016 and 14420 patients will die of their disease [1]. Widespread usage of cross-sectional imaging and ultrasound for other medical conditions have led to a shift towards detection of earlier stages of RCC $[2,3]$. Nevertheless, about $10 \%$ of all patients diagnosed with
RCC have metastasis at presentation and another $20-30 \%$ of patients will develop metastasis despite an initially curative treatment approach [4].

The most common sites of metastasis in RCC include lung (60\%), bone (35\%) liver $(20 \%)$ and brain $(10 \%)[5,6]$. Bone metastasis include rib and pelvis $(50 \%)$ as well as spine (40\%), often leading to significant pain in patients and decrease in quality of life [7]. Therefore, limiting bone metastasis in patients with advanced renal cell carcinoma is a crucial treatment goal. 
The calcium-sensing receptor (CaSR), a G-protein coupled receptor, is involved in the normal calcium and phosphate homeostasis, renin release as well as in the acidification and concentration of urine [8-10] and therefore highly expressed in normal kidney tissue [11]. With an increase in extracellular calcium, CaSR respond with an activation of several intracellular signaling pathways, leading to changes in cell proliferation, apoptosis and migration [12]. In other cancers such as breast and prostate cancer, the expression of CaSR has been identified to correlate with an increased affinity of the cancer towards development of bone metastasis $[13,14]$. Our group has recently identified the same finding in a subset of patients with metastatic RCC [15]. Objective of this study was to evaluate the effect of CaSR overexpression on the development of bone metastasis in vitro and in vivo.

\section{RESULTS}

\section{CaSR transfection of RCC cells was successful}

To evaluate the success of CaSR gene transfection in the 786-O cells, PCR, Western blot and flow cytometry analyses were performed. The CaSR-transfected cell line showed a much higher CaSR expression than vectortransfected control cells (Supplementary Figure 1). Therefore, these cells were selected for the functional assays.

\section{Calcium induced an increase in cell adhesion, migration and proliferation of CaSR-transfected 786-O cells in vitro}

To evaluate the steps of metastasis, cell adhesion on endothelial cells, adhesion on ECM compounds, migration with calcium as chemoattractant was used and cell proliferation was measured, depending on calcium treatment. The use of calcium as a CaSR activator led to a significant increase of cell adhesion to endothelial cells (5.3 \pm SEM or SD-fold, $p<0.0001$, Figure 1$)$ as well as adhesion to fibronectin (3.5-fold, $p=0.017$, Figure $2 \mathrm{~A}$ ) and collagen type I (4.2-fold, $p<0.001$, Figure $2 \mathrm{~B}$ ) in the CaSR transfected 786-O cells. The adhesion to collagen type IV (Figure 2C) and to the BSA negative control were unchanged (Figure 2D). The chemotactical cell migration using calcium as a chemoattractant (Figure 3 ) and cell proliferation (Figure 4) were also significantly enhanced in CaSR transfected 786-O cells, 88-fold ( $p=0.002)$ and 1.9 -fold ( $p=0.027$ ), respectively. By the combinatory use of calcium and NPS2143, a specific CaSR inhibitor, the observed effects of the calcium treatment were reversed nearly down to normal activities (Figures 1-4). The optimal concentration of $10 \mu \mathrm{M}$ NPS2143 was determined using a MTT-based cell viability assay (Supplementary Figure 2).

\section{CaSR activation induced enhanced MAPK and AKT signaling}

To get an overview about the effect of calcium on the activation of intracellular signaling pathways a human phospho-kinase array was accomplished using CaSR-transfected 786-O cells. Those signal transduction mediators which were sensitive for calcium in CaSRtransfected cells but not in control cells (Supplementary Figure 3) were verified by Western blot analysis. In 786-O cells the AKT and MAPK signaling pathways were activated by calcium in CaSR-transfected, but not in vector-transfected cells. Activation of CaSR resulted in enhanced phosphorylation of the CaSR downstream targets SHC, AKT, ERK, JNK and p90RSK. These effects were abolished by the CaSR antagonist NPS2143 (Figure 5).

\section{Overexpression of CaSR led to a higher rate of bone metastasis in vivo}

After intracardiac injection of the CaSR and luciferase transfected 786-O cells in mice, the first metastases were detected after 31 days. Location of the metastasis was precisely determined by initial detection with bioluminescence, followed by MRI in representative cases and final confirmation with histopathology (Figure 6A). At the end of the experiment (day 69), we detected 16 metastases in 11 mice, $75 \%$ of which were located in bones. In our xenograft model, overexpression of CaSR in the 768-O cells led to a significant increase in bone metastases compared to vector-transfected $768-\mathrm{O}$ cells. We saw a total of 8 bone metastases in CaSR group and 4 bone metastases in the vector group (Figure 6B). The percentage of metastases per total number of mice was $72.73 \%$ in the CaSR and $30.77 \%$ in the vector group ( $p=0.0142$ ) (Figure 6C). Mice injected with CaSR overexpressing cells showed the first bone metastasis earlier than mice injected with control cells (Figure 6D). In total 8 of 24 injected mice $(25 \%)$ had relevant bone metastasis. Table 1 shows the frequency of the metastatic distribution, with $43.75 \%$ located in the jaw of the animals.

\section{DISCUSSION}

Cancer research has been elucidating mechanisms of metastasis for decades. The explanation of the preference of cancer cell colonies to specific metastatic sites is not fully understood. However, the interaction of the cancer cells of the initial tumor with the microenvironment of the site of metastasis seems of great importance. 


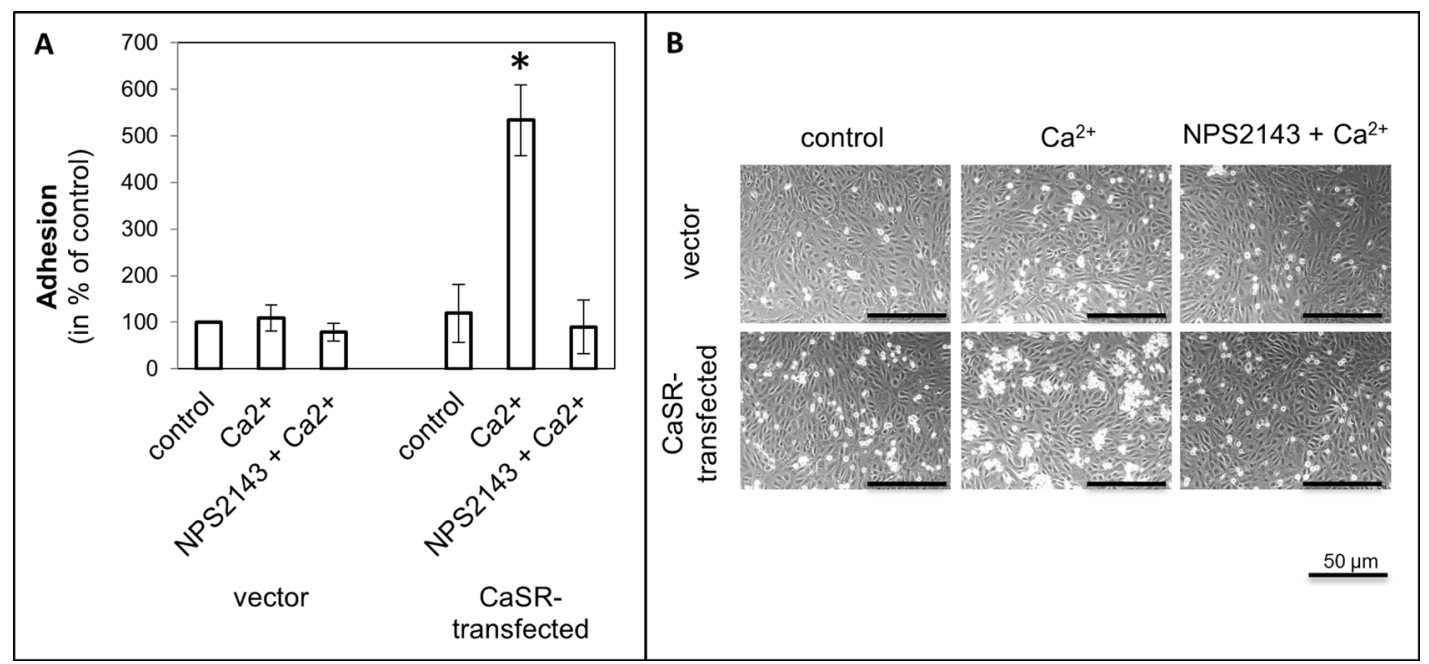

Figure 1: Cell adhesion of CaSR-transfected 786-O cells on endothelial cells (HUVEC). Cells were treated with calcium $(5 \mathrm{mM})$ or a combination of calcium $(5 \mathrm{mM})$ and NPS2143 $(10 \mu \mathrm{M})$. (A) The adhesion value is shown as percentage of the adhesion of untreated vector-transfected cells. (B) Microscopic images of cell adhesion on HUVEC. Calcium triggered cell adhesion on HUVEC in CaSR-transfected cells significantly. Significance was calculated by Student's $T$-test, $p<0.05$.

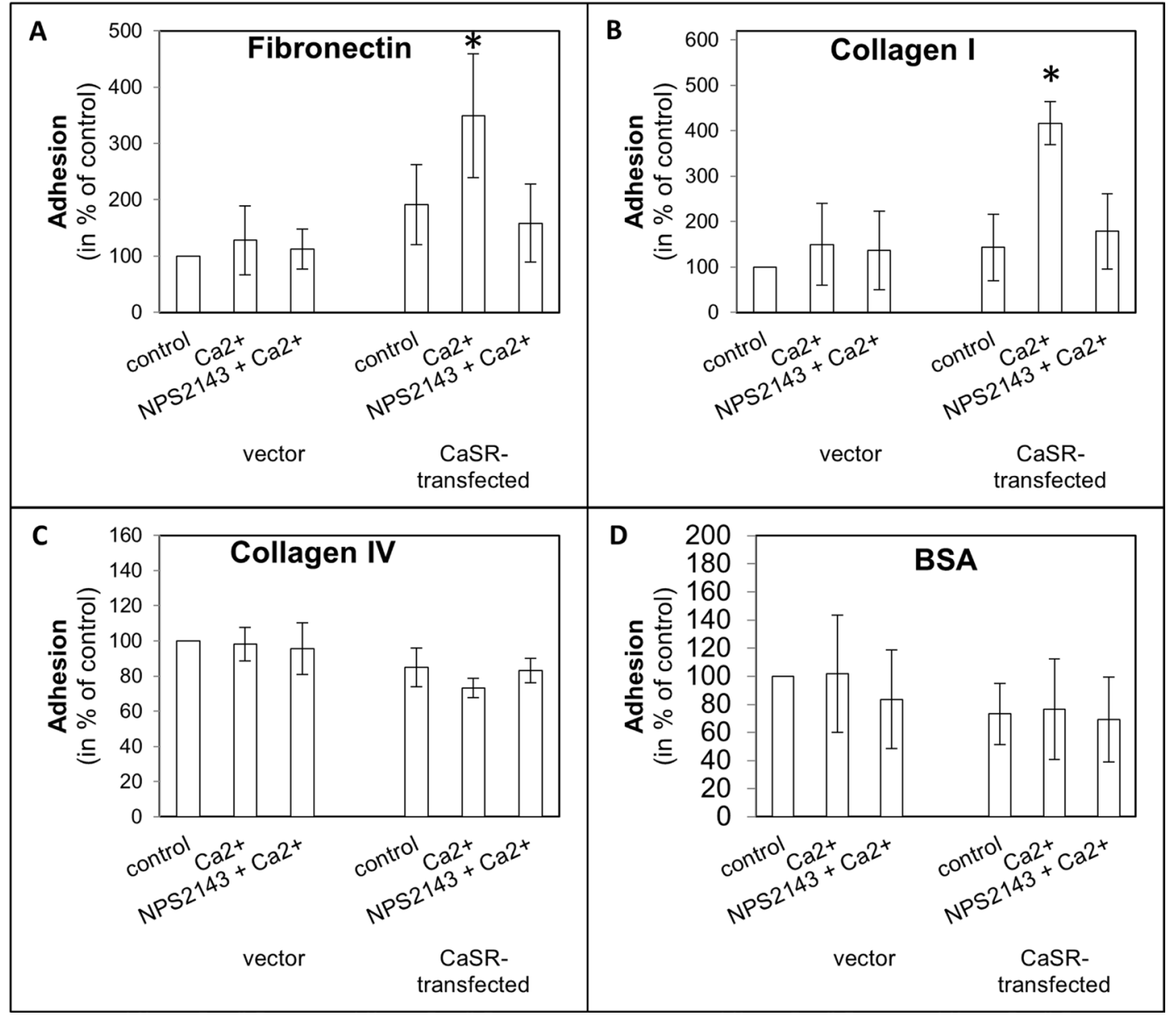

Figure 2: Cell adhesion of CaSR-transfected 786-O cells on extracellular matrix components fibronectin (A), collagen I (B), collagen IV (C) and BSA (D). Cells were treated with calcium $(5 \mathrm{mM})$ or a combination of calcium $(5 \mathrm{mM})$ and NPS2143 $(10 \mu \mathrm{M})$. The adhesion value is shown as percentage of the adhesion of untreated vector-transfected cells. BSA was used as control. Calcium triggered cell adhesion on fibronectin and collagen I in CaSR-transfected cells significantly. Significance was calculated by Student's $T$-test, $p<0.05$. 
During bone metastasis cells invade the calcium rich bone structure and increase the bone turnover by interacting with osteoclasts and osteoblasts, resulting in high levels of extracellular calcium, numerous growth factors and cytokines in the tumor microenvironment [16]. Cancer cells metastasizing to the bone may benefit from this unique condition by increased attraction of cancer cells as well as facilitation of metastatic seeding and proliferation. In contrast, treatments such as bisphosphonates or RANK-ligand (RANKL) inhibitors have shown to change this environment by inhibition of osteoclast activity and osteoclastogenesis leading to tumor cell apoptosis $[17,18]$.

The calcium-sensing receptor plays an important role in the recognition of calcium levels [19]. It is not only responsible for maintaining calcium hemostasis by regulation of the parathyroid hormone, but also appears to play a crucial role in the development of bone metastases in several cancers such as breast and prostate cancer [13, 20-22]. Chirgwin et al. proposed a kind of vicious circle where the tumor cells secrete parathyroid hormonerelated protein $(\mathrm{PTHrP})$ after calcium stimulation, which

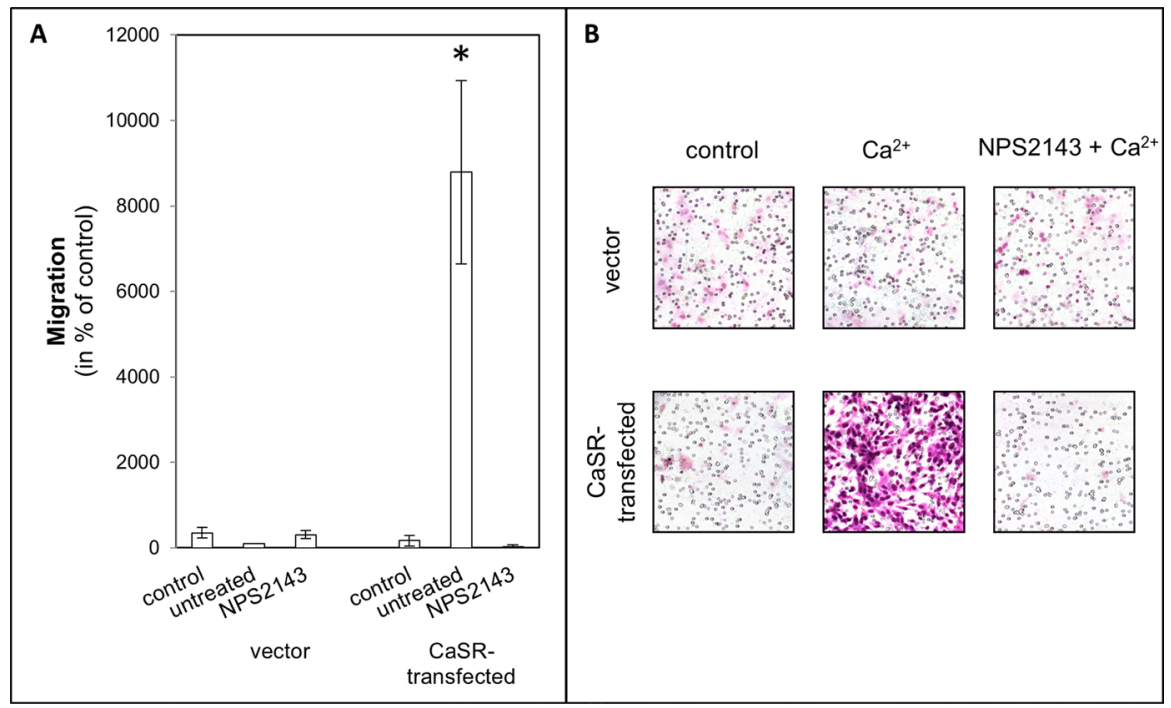

Figure 3: Chemotactical cell migration of CaSR-transfected 786-O cells using calcium as chemotaxin. Cells were treated with NPS2143 $(10 \mu \mathrm{M})$. Migration was determined in a Boyden chamber using serum-free medium as control or calcium $(5 \mathrm{mM})$ as chemotaxin. (A) The migration value is shown as percentage of the migration of untreated vector-transfected cells. (B) Microscopic images of migrated cells. CaSR-transfected cells showed a significant increased migration. Significance was calculated by Student's $T$-test, $p<0.05$.

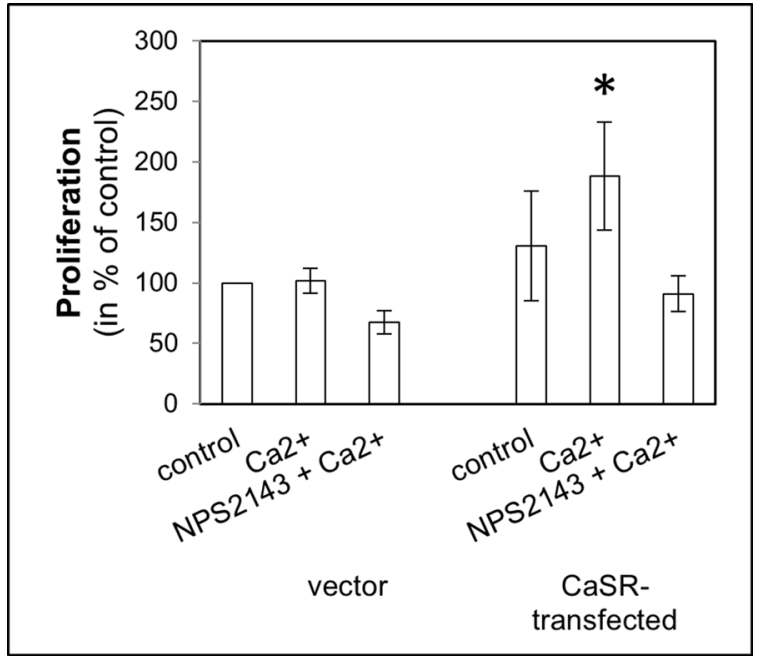

Figure 4: Cell proliferation of CaSR-transfected 786-O. Cells were treated with calcium (5 mM) or a combination of calcium $(5 \mathrm{mM})$ and NPS2143 $(10 \mu \mathrm{M})$. The proliferation value is shown as percentage of the proliferation of untreated vector-transfected cells. Calcium triggered cell proliferation in CaSR-transfected cells significantly. Significance was calculated by Student's $T$-test, $p<0.05$. 
results in an increased RANKL expression on immature osteoblasts. This in turn activates osteoclastogenesis via RANK on osteoclast precursors, leading to an increase in osteolysis and consequently to increasing calcium concentration in the tissue, again stimulating tumor cells. Furthermore, growth factors and cytokines like TGF $\beta$,
PDGF and IGF1 are released during osteolysis, which have a proliferation inducing effect on tumor cells and additionally promote bone metastasis progression [23, 24].

Boudot et al. recently showed that a CaSR overexpression could be linked to an increase of the osteolytic potential of breast cancer cells [25]. In prostate

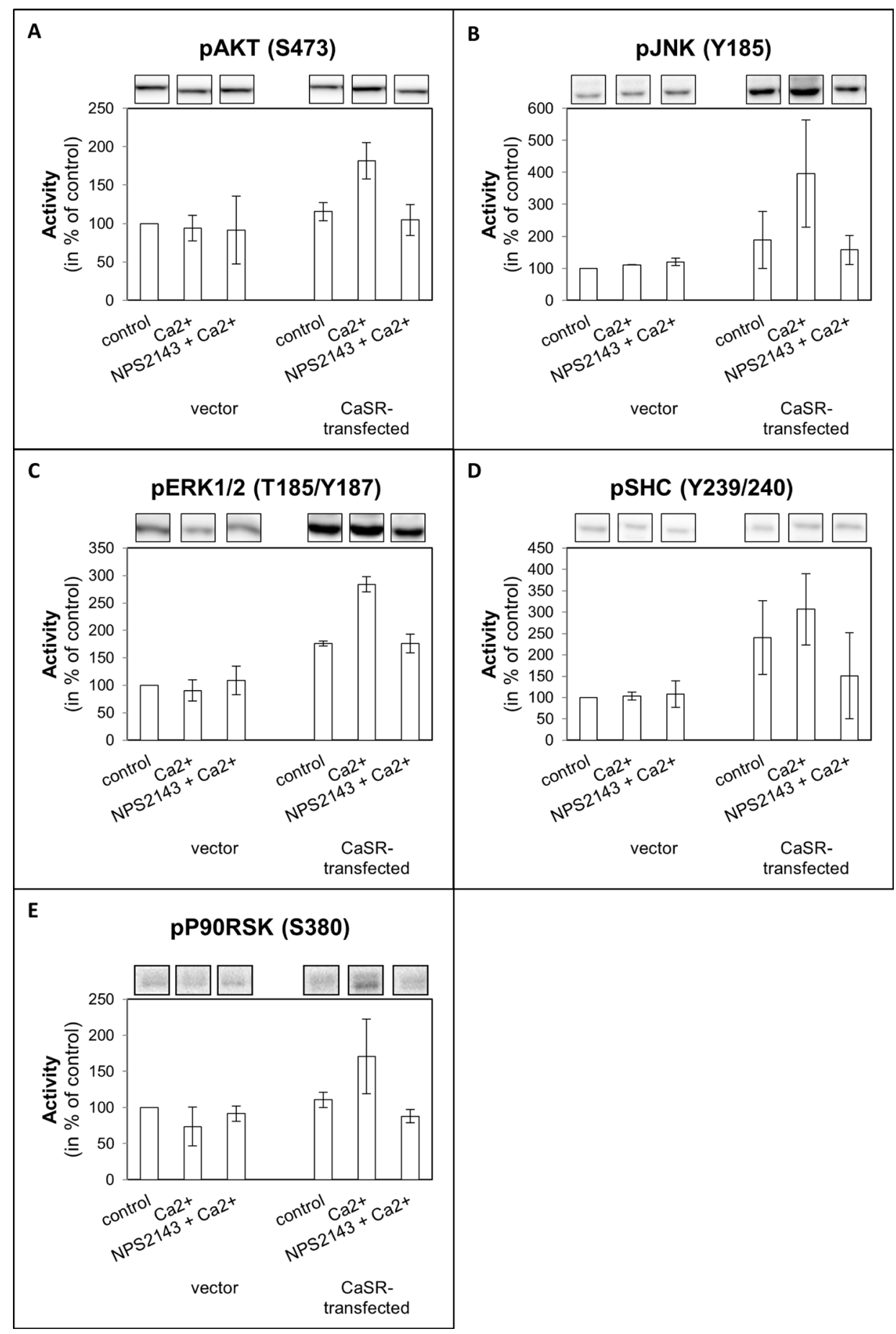

Figure 5: Activity of (A) AKT, (B) JNK, (C) ERK1/2, (D) SHC, and (E) P90RSK of CaSR-transfected 786-O. Cells were treated with calcium $(5 \mathrm{mM})$ or a combination of calcium $(5 \mathrm{mM})$ and NPS2 $143(10 \mu \mathrm{M})$. The activity value is shown as percentage of untreated vectortransfected cells. Exemplary Western blot bands are shown above the diagram. Calcium triggered activity of AKT, JNK, ERK1/2, SHC and P90RSK in CaSR-transfected cells. 
Bioluminescence measured by IVIS 360 degrees

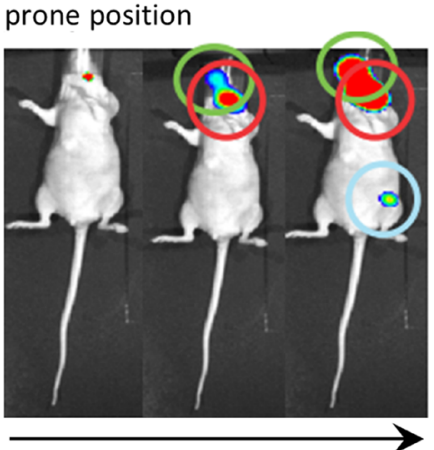

increasing sensitivity left side up

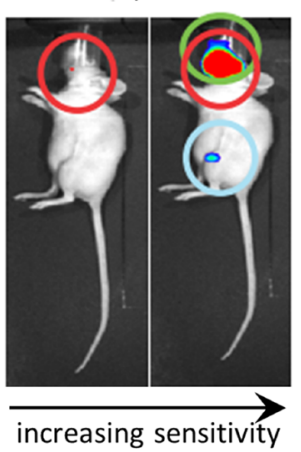

supine position

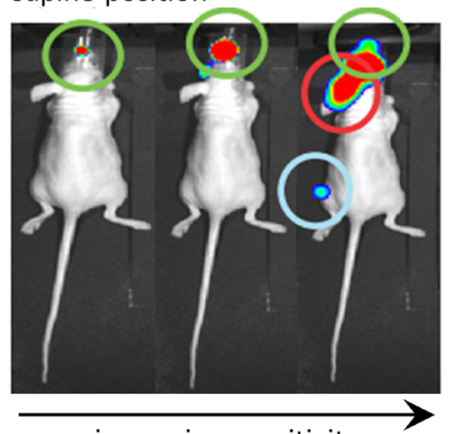

increasing sensitivity

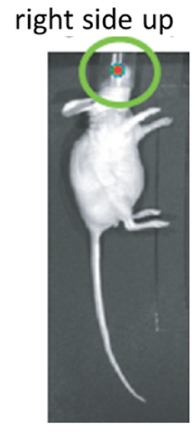

MRI images

metastasis nasal bone

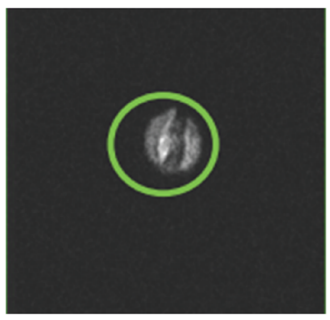

metastasis left jaw

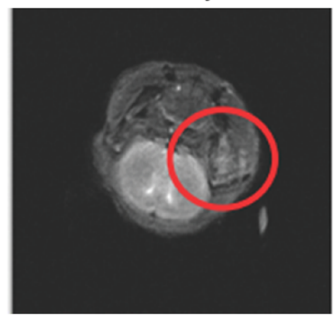

metastasis left knee

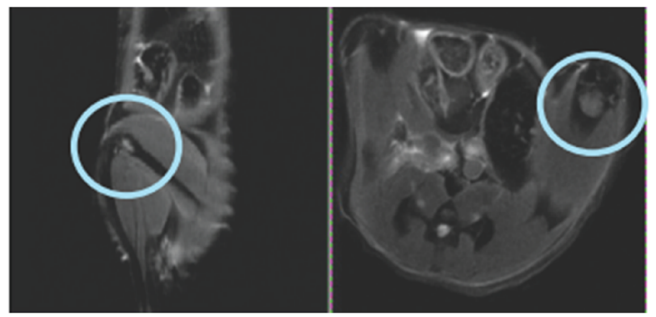

Histological images metastasis nasal bone

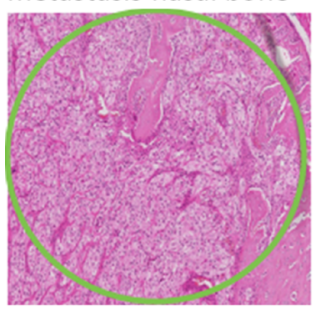

metastasis left jaw
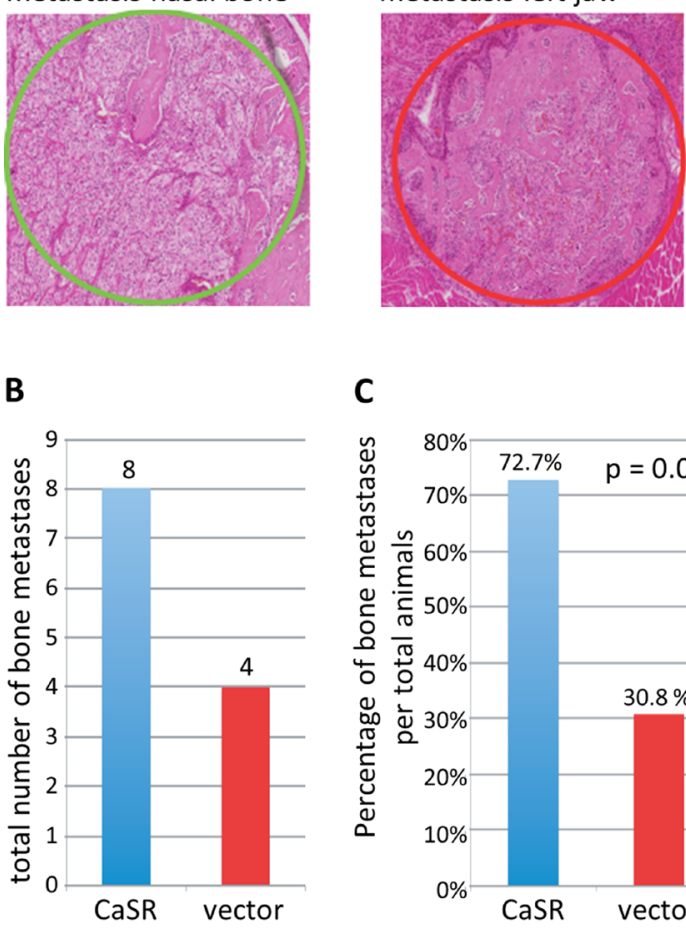

injected cells
C

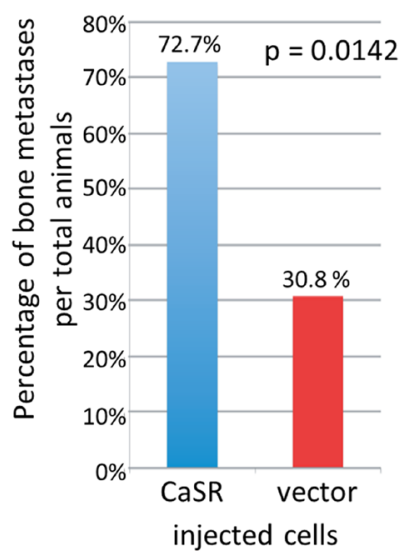

metastasis left knee

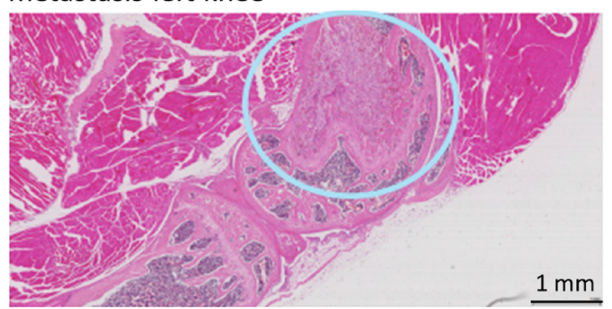

D

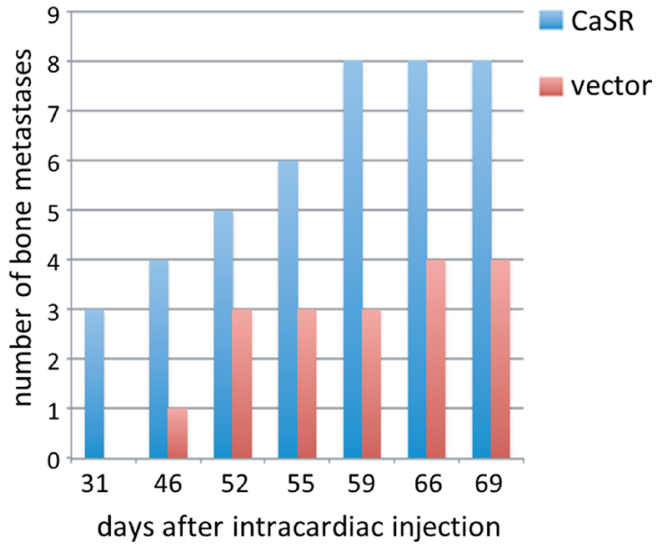

Figure 6: Development of bone metastases after intracardiac injection of CaSR overexpressing cells into a xenograft mouse model. Detection of bone metastases using bioluminescence (IVIS), representative MRI-images and histopathology (A) (representative images shown - each single lesion is represented by one color) confirmed a higher number of total bone metastases (B) as well as a higher number of bone metastases per total animals $(\mathbf{C})$ (Students $T$-Test, $p<0.05$ ) and an earlier development of bone metastases (D) for the CaSR overexpressing cells. 
Table 1: Frequencies of relevant metastatic locations after 69 days

\begin{tabular}{lccc}
\hline Location of metastasis & CaSR overexpressing cells & Vector & Total \\
\hline Spine & $2(22.2 \%)$ & 0 & $2(12.5 \%)$ \\
Jaw & $4(44.4 \%)$ & $3(42.86 \%)$ & $7(43.75 \%)$ \\
Extremities & $1(11.1 \%)$ & 0 & $1(6.25 \%)$ \\
Pelvis & $1(11.1 \%)$ & $1(14.29 \%)$ & $2(12.5 \%)$ \\
Muscle & $1(11.1 \%)$ & $1(14.29 \%)$ & $2(12.5 \%)$ \\
Heart & 0 & $2(28.57 \%)$ & $2(12.5 \%)$ \\
Total number of metastasis & $9(100 \%)$ & $7(100 \%)$ & $16(100 \%)$ \\
Total number of bone metastasis & $8(66 \%)$ & $4(33 \%)$ & $12(100 \%)$ \\
Total number of animals & 11 & 13 & 24 \\
\hline
\end{tabular}

cancer a similar mechanism with involvement of prostate specific antigen (PSA) and endothelin-1 (ET-1) has been described [26].

As the kidney plays a crucial role in calcium homeostasis in healthy tissue, CaSR is widely expressed in normal and malignant renal tissues [11]. We recently demonstrated that the expression of CaSR was highest in specimens and primary cells of patients with renal cell carcinoma who developed bone metastases in a period of five years after surgery [15]. Based on this observation we generated the hypothesis that overexpression of CaSR may result in an increase of cellular processes, which trigger bone metastasis. It is a well-established concept that due to their osteolytic characteristics, RCC bone metastases lead to high calcium levels in serum [7], potentially inducing enhanced cellular activity of CaSR-expressing tumor cells. In fact, we here show that overexpression of CaSR induced calcium-dependent a higher adhesion, migration and proliferation potential in RCC cell line 786-O in vitro, suggesting that enhanced CaSR expression in RCC cells results in increased bone metastasis.

Metastatic progression is a multistep process including several cellular processes. The first step of metastatic progression is the adhesion of the tumor cells on the endothelium. In bone metastases, tumor cells are attracted to the bone by various extracellular components and also by free calcium ions. The adhesion potential on the extracellular matrix differed in our study depending on the compound. The adhesion potential to fibronectin and collagen type I but not to collagen type IV was increased. Collagen I is the main component of the organic part of the bone, and fibronectin is also highly concentrated in bone tissue [27], so that both seem to chemoattract RCC cells. In contrast, collagen IV is mainly found in the basal lamina of blood vessels, less developed in bone due to the fenestrated character of the endothelium [28]. This supports the hypothesis that expression of CaSR guides the tumor cells to the bone and emphasized the organ-specific metastasis of tumor cells. The CaSR inhibitor NPS2143 revised the described cellular effects, demonstrating its CaSR dependence.
These results show that in our cell system calcium, via CaSR, induces enhanced metastatic behavior of RCC cells leading to the development of bone metastasis. A contribution of the calcium-sensing receptor to cell adhesion and migration via integrin signaling was already shown by Tharmalingam et al. in medullary thyroid carcinoma cells [29]. Tumor cells harboring the calciumsensing receptor could enhance these cellular processes downstream via the integrin signaling cascade and also via the CaSR signaling cascade itself. Downstream targets are primarily the AKT and MAPK signaling cascade. We analyzed intracellular signaling pathways involved in the CaSR dependent metastatic behavior of the RCC cells and found a significance of MAPK and AKT signaling cascades. Kinase activity of the MAPK, JNK, ERK1/2 and p90RSK as well as the kinase AKT was enhanced after stimulating CaSR-transfected tumor cells with calcium. An enhanced activity was also found for the upstream adapter protein SHC. As already shown in our functional cell analyses, as documented by using the CaSR inhibitor NPS2143, the effect of cell signaling were CaSR dependent. A contribution of the MAPK and AKT signaling pathways in these processes was already shown in breast cancer cells by Saidak et al. and in primary RCC cells in our former investigation $[15,30]$. In prostate cancer an increase in skeletal metastasis has been associated with AKT signaling [20].

The CaSR seems to induce metastasis by activating adhesion and migration. Besides these processes, another important step of metastatic progression is the maintenance of cell proliferation. Tumor cells reaching the bone microenvironment are exposed to high calcium concentrations, which in return activate the receptor. It has been shown that CaSR is able to trigger cell proliferation in smooth muscle cells as well as in pancreatic $\beta$-cells $[31,32]$. Our results support the hypothesis that CaSR guides the tumor cells to the bone and the development of organ-specific metastasis of tumor cells. Therefore, the compatibility between the tumor cells ("the seed") and the microenvironment ("the soil") has to fit for a successful metastatic spread [33]. 
We confirmed our in vitro results by intracardiac cell injections in a xenograft mouse model in vivo. Detection of metastasis is highly sensitive in this animal model and has the great benefit of enabling a continuous monitoring [34]. Mice injected with CaSR-transfected tumor cells showed a higher rate of bone metastases in total as well as an earlier occurrence of metastases compared to mice that were injected with vector-transfected cells.

This indicates a contribution of AKT and MAPK pathways after calcium dependent stimulation of CaSR in triggering cell migration, adhesion and proliferation, thus enhancing bone metastasis (Figure 7). Our results propose CaSR as a potent target preventing bone metastasis in renal cancer. NPS2143, a calcilytic drug [35], may serve as a new therapeutic agent. Marquis et al. showed that NPS2143 had a good specificity with only a few additional targets like monoamine transporters [36], which may lead in minor side effects. It was recently tested for osteoporosis treatment and calcium hemeostasis related diseases [37-39], and in vivo has demonstrated a good biocompatibility [40, 41]. Thus, RCC patients with bone metastases and increased CaSR expression might benefit from a therapy with antagonists like NPS2143, justifying further preclinical and clinical development.

\section{CONCLUSIONS}

Our results identify CaSR as an important promoter of bone metastasis in RCC. The receptor is responsible for a calcium-dependent increase in cell migration, adhesion and proliferation resulting in an increase of bone metastases. Therefore, targeting CaSR may be beneficial in patients with bone metastases of RCC with high CaSR expression and development of CaSR as a therapeutic target is warranted.

\section{MATERIALS AND METHODS}

\section{Cells, cell culture and treatment}

Human renal cell carcinoma cell line $768-\mathrm{O}$ was obtained from LGC Promochem (Wesel, Germany). Cells were cultured in AmnioMAX C100 Basal Medium supplemented with AmnioMAX C-100 Supplement (Gibco). The cell line was incubated in a moistened atmosphere at $5 \% \mathrm{CO}_{2}$ at $37^{\circ} \mathrm{C}$. Every time cells were passaged they were washed with sterile DPBS, and detached by using $2.5 \%$ trypsin-EDTA. Cells were centrifuged at $300 \mathrm{~g}$ for five minutes and resuspended in culture medium. For the experiments, cells were treated with calcium alone ( $5 \mathrm{mM}, 30 \mathrm{~min}$, serum-free) or alternatively with the CaSR antagonist NPS2143 $(10 \mu \mathrm{M}$, $30 \mathrm{~min}$, serum-free) and afterwards with the combination of NPS2143 $(10 \mu \mathrm{M})$ and calcium $(5 \mathrm{mM})$ for further 30 min. Serum-free medium served as a control.

\section{CaSR transfection}

The human CaSR gene (full length) was cloned into a pcDNA3 vector system (Invitrogen) containing a

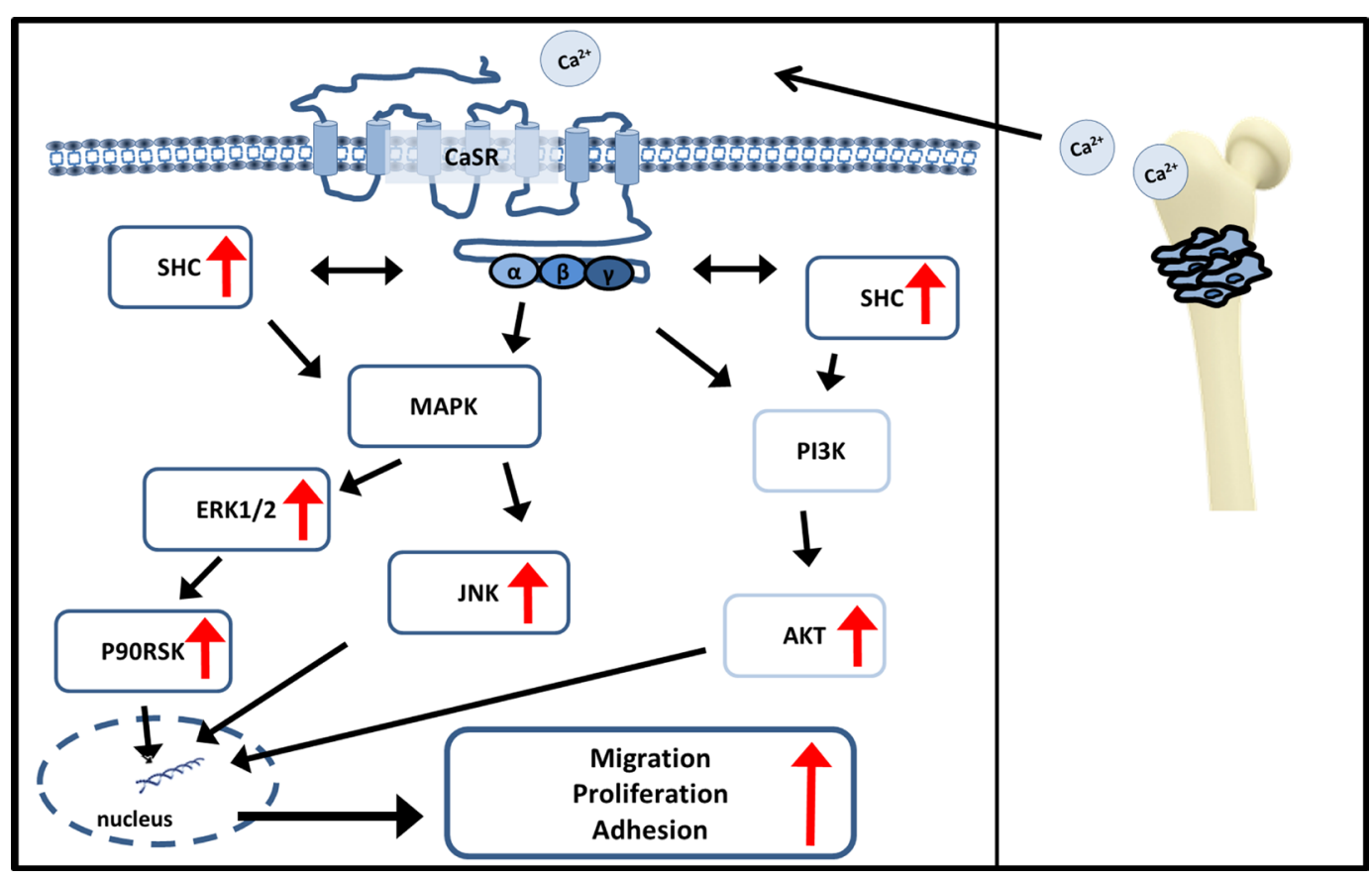

Figure 7: Signaling pathways influenced by CaSR. CaSR, stimulated by calcium, triggers AKT activity as well as MAPK activity of JNK, ERK1/2, p90RSK and SHC activity. Both signaling pathways lead downstream to an increase in cellular processes like cell migration, proliferation and adhesion. Red arrows show increased activity in CaSR overexpressing cells after Calcium stimulation. 
gentamycin selection gene. The plasmid was prepared by using the Qiagen plasmid maxi kit (Qiagen). 786-O cells were stably transfected using Turbofect transfection reagent (Thermo Scientific, USA). 786-O cells were seeded at $2 \times 10^{5}$ cells/well in a 6-well-plate in serum-free medium and incubated overnight at $37^{\circ} \mathrm{C}$. Next, $4 \mu \mathrm{g}$ of plasmid DNA (CaSR) were diluted in $400 \mu 1$ serum-free medium, immediately mixed with $6 \mu 1$ of Turbofect each and incubated for $20 \mathrm{~min}$ at room temperature for complex formation. $400 \mu \mathrm{l}$ of transfection mixture were carefully suspended into each well of the 6-well-plate. After $36 \mathrm{~h}$ the medium was changed to the selection medium containing $400 \mathrm{mg} / \mathrm{ml}$ gentamycin. As negative controls we used the empty vector. The effectiveness of the CaSR overexpression was determined using flow cytometry, PCR and Western blot analyses.

\section{Luciferase transfection for in vivo experiments}

For in vivo experiments CaSR transfected (786-O-CaSR) or empty vector transfected 768-O cells (786-O-vector) were additionally infected with a lentivirus containing the firefly luciferase gene as previously described [42]. Briefly, $10 \mu \mathrm{g}$ of the transducing vector, FUGWB plasmid was mixed with $10 \mu \mathrm{g}$ of packaging vector pR8.91 and $5 \mu \mathrm{g}$ of plasmid encoding vesicular stomatitis virus glycoprotein(VSV-G) with the addition of $37 \mu 1$ of $\mathrm{CaCl}_{2}$ (2 M, pH 7.2). The DNA-calcium complex was mixed with $250 \mu \mathrm{l}$ of $2 \mathrm{x}$ HEPES buffered solution and after 30 min incubation was added to 293T cells. After $24 \mathrm{~h}$ the medium was replaced and after additional $24 \mathrm{~h}$ the supernatant was collected, filtered through a $0.45 \mu \mathrm{m}$ filter and used to infect the 768-O cells. Blasticidin at a concentration of $5 \mu \mathrm{M}$ was used to select the transduced cells. A PCR was performed after the transfection of both plasmids to confirm the overexpression of CaSR in the $768-\mathrm{O}$ cells. In addition the cells were tested in vitro for luciferase activity (data not shown).

\section{Flow cytometry}

Quantification of CaSR expression was performed by flow cytometry as described previously [15]. The cells $\left(2 \times 10^{6} \mathrm{cells} / \mathrm{ml}\right)$ were fixed using $4 \%$ paraformaldehyde for $10 \mathrm{~min}$. Mouse monoclonal anti-CaSR antibody (Novus Biologicals, USA) was used in a 1:1000 dilution. Mouse anti-human isotype control immunoglobulins (Dako, Carpinteria, USA) was used in the same concentration in PBS containing $1 \%$ bovine serum albumin (BSA) for $60 \mathrm{~min}$ at $4^{\circ} \mathrm{C}$. After washing with PBS the secondary antibody (alexa flour 488 goat antimouse) was diluted 1:1000 in 1\% BSA/PBS and incubated for $20 \mathrm{~min}$ at $4^{\circ} \mathrm{C}$ in darkness. Cells were washed again and CaSR expression was quantified in a flow cytometer (BD Calibur, Becton Dickinson, Heidelberg, Germany).

\section{Cell adhesion to the endothelial cells}

Human umbilical vein endothelial cells (HUVEC, $5 \times 10^{5}$ cells/well) were cultivated on 6-well-plates, previously coated with $0.2 \%$ gelatin solution for $30 \mathrm{~min}$ at $37^{\circ} \mathrm{C}$, in a $\mathrm{CO}_{2}$ incubator to a confluent monolayer. $5 \times 10^{5}$ of transfected $786-\mathrm{O}$ cells were transferred into the 6-well-plates for $2 \mathrm{~h}$ at $37^{\circ} \mathrm{C}$ in a humidified atmosphere containing $5 \% \mathrm{CO}_{2}$ in air. Cells were washed with DPBS and fixed for 10 min with $1 \%$ glutaraldehyde. Quantification was performed by counting adherent cells, which could be distinguished from HUVEC on the basis of their shape. The adherent cells were counted in five different fields with an area of $156,35 \mathrm{~mm}^{2}$ each, using a raster ocular.

\section{Cell adhesion to ECM compounds}

Cell adhesion assay to ECM compound was performed as described previously [43], using a ReactiBind $^{\mathrm{TM}}$ amine binding 96-well-plate, coated with fibronectin, collagen I and IV or BSA (all $10 \mu \mathrm{g} / \mathrm{ml}$ ) as control over night. On the next day, wells were washed twice with DPBS with $0.05 \%$ Tween 20 . Unspecific binding sites were blocked with $200 \mu$ l blocking solution (DPBS with $0.5 \%$ BSA) per well and incubated for one hour in a moistened atmosphere at $5 \% \mathrm{CO}_{2}$ at $37^{\circ} \mathrm{C}$ in air. Meanwhile cells were detached with trypsinEDTA and treated for 30 minutes with calcium and/or NPS2143, respectively. Blocking solution was removed and $50 \mu \mathrm{l}$ of tumor cell suspension $\left(4 \times 10^{5}\right.$ cells/ $\mathrm{ml})$ per well were added. After one hour incubation in a moistened atmosphere at $5 \% \mathrm{CO}_{2}$ and $37^{\circ} \mathrm{C}$, nonadherent cells were washed out with $2 \times 200 \mu 1$ washing buffer per well. Adherent cells were fixed with $100 \mu \mathrm{l}$ $4 \%$ paraformaldehyde (Histofix 4\%, Roth) per well for 15 minutes at room temperature. Adherent and fixed cells were stained using $100 \mu \mathrm{l}$ crystal violet solution $(5 \mathrm{mg} / \mathrm{ml} \mathrm{in} 2 \%$ ethanol) for 10 minutes at room temperature. Afterwards the staining solution was washed out and the plate was air-dried. For resolving the colorant wells were incubated with $100 \mu \mathrm{l} 2 \%$ SDS (Roth) for 30 minutes on a rocking shaker. The absorbance was measured at $550 \mathrm{~nm}$ (reference value at $650 \mathrm{~nm}$ ).

\section{Cell migration assay}

Cell migration was quantified in a microchemotaxis chamber (Boyden chamber, Costar, Cambridge, USA) including a porous polycarbonate membrane (pore diameter $8 \mu \mathrm{m}$; Neuroprobe Inc., Gaithersburg, USA) with a surface of approximately $7.8 \mathrm{~mm}^{2}$ per well [44]. Before analysis cells were cultivated in serumfree culture medium for 24 hours. The lower part of the chamber was filled with $29 \mu$ l (manufacturer's instruction) calcium (10 mM, according to the Calcium concentration in bone [45]) in serum-free medium or 
medium alone as control. The upper chamber part was loaded with $50 \mu \mathrm{l}$ of the tumor cell suspension $\left(3 \times 10^{5}\right.$ cells $/ \mathrm{ml}$ ) followed by an incubation step of $16 \mathrm{~h}$ at $37^{\circ} \mathrm{C}$ in a humidified atmosphere containing $5 \% \mathrm{CO}_{2}$ in air. Cells that did not pass the polycarbonate membrane were removed from the upper side of the porous membrane by washing with a Weise buffer (Merck, Darmstadt, Germany; a potassium dihydrogen phosphate buffer, $\mathrm{pH}$ 7.0) and by mechanic removal using a cell scraper. Membranes were dried and fixed in methanol for $1 \mathrm{~min}$ followed by immediately staining with hemacolor (Merck). The dyed membrane was transferred to a microscope slide and covered with immersion oil. Cell migration capability was evaluated thereafter (Zeiss, 400-fold magnification). For a single determination, ten different views per well with a combined membrane surface of $2.5 \mathrm{~mm}^{2}$ were evaluated. Experiments were performed in quadruplicates. From the results a mean value and a standard error were calculated [46].

\section{Cell proliferation assay}

Cell proliferation experiments were performed using a colorimetric BrdU incorporation assay (Roche, Mannheim, Germany) [47].Transfected cells were seeded on a 96-well-plate $\left(5 \times 10^{3}\right.$ cells/well $)$, cultured for $48 \mathrm{~h}$ and treated in quadruplicates with calcium or calcium and NPS2143, as described. BrdU solution was added to the cells without replacing the NPS2143 and/or calcium containing culture medium and incubated for $2 \mathrm{~h}$ in presence of calcium at $37^{\circ} \mathrm{C}$ in a $\mathrm{CO}_{2}$ incubator. Tumor cells were fixed and DNA was denatured in one step by adding fixDenat ${ }^{\mathrm{TM}}$ solution for $30 \mathrm{~min}$. Incorporated BrdU was detected by an anti-BrdU-POD antibody within $60 \mathrm{~min}$. The resulting immune complex was detected by a subsequent substrate reaction and quantified by measuring the absorbance at $450 \mathrm{~nm}$ (reference wavelength $690 \mathrm{~nm}$ ).

\section{MTT assay}

Cell viability after treatment with NPS2143 was analyzed using MTT assay (3,(4,5-Dimethylthiazol-2 yl)2,5-Diphenyl-Tetrazoliumbromid). Cells were seeded on a 96-well-plate $\left(5 \times 10^{3}\right.$ cells/well $)$, cultured for $24 \mathrm{~h}$ and treated in quadruplicates with increasing concentrations of NPS2 143 in a range from $100 \mathrm{nM}$ to $100 \mu \mathrm{M}$. After $24 \mathrm{~h}$ $20 \mu \mathrm{l}$ of MTT $(0.5 \%)$ was added. After an incubation of $3 \mathrm{~h}$ at $37^{\circ} \mathrm{C}$ in $5 \% \mathrm{CO}_{2}$ atmosphere, cells were washed with $200 \mu \mathrm{l}$ DBPS. The wells were incubated with $100 \mu \mathrm{l}$ isopropyl alcohol for $15 \mathrm{~min}$ and absorbance at $570 \mathrm{~nm}$ was measured [48].

\section{Human phospho-kinase array}

The activity of 45 intracellular signaling kinases was quantified by using a human phospho-kinase array (R\&D, Minneapolis, USA). Protein extracts from CaSR or empty vector transfected 786-O cells, were prepared by using $200 \mu \mathrm{l}$ lysis buffer included in the kit. Cells were scraped off with a cell scraper in $400 \mu \mathrm{l}$ of lysis buffer of the kit. All further steps were performed in accordance with the instructions in the manual. Protein concentrations were determined using BCA (bicinchoninic acid) reagent (Thermo Scientific, Rockford, USA). For the analysis $300 \mu \mathrm{g}$ protein was used. The provided membranes were incubated with array buffer 1 for $1 \mathrm{~h}$ on a rocking platform. On each membrane $1 \mathrm{ml}$ of the protein lysates $(300 \mu \mathrm{g})$ were added and incubated overnight at $4^{\circ} \mathrm{C}$ on a rocking platform. After a triple washing step (washing buffer) membranes were incubated in antibody cocktails for $2 \mathrm{~h}$ on a rocking platform. After a $30 \mathrm{~min}$ treatment with streptavidin-HRP solution, membranes were exposed to a chemiluminescent reagent. Positive signals were visualized using a chemiluminescence imaging system. The amount of protein in each spot was calculated by using image software provided by the chemiluminescence Imaging System.

\section{Western blot analysis}

For preparation of protein extracts, 786-O cells were cultivated on $10 \mathrm{~cm}$ sterile dishes. Reaching semiconfluent growth, cells were cultured in serum free media for $24 \mathrm{~h}$ followed by treatment with calcium or a combination of calcium and NP2143 as described above. Afterwards cells were covered with $500 \mu \mathrm{l}$ cell lysis buffer (2 mM HEPES, pH 7.7, $0.02 \mathrm{M} \mathrm{NaCl}, 0.05 \mathrm{mM}$ $\mathrm{MgCl}_{2}, 0.04 \mathrm{mM}$ EDTA, $0.1 \%$ Triton X-100, $5 \mu \mathrm{M}$ DTT including $1 \%$ protease and phosphatase inhibitors (Sigma, Steinheim, Germany)) /dish. Cells were mechanically removed from the surface using a sterile cell scraper transferred to a tube and immediately vortexed. After $30 \mathrm{~min}$ incubation on ice the extracts were centrifuged at $14000 \mathrm{~g}, 4^{\circ} \mathrm{C}$ for $10 \mathrm{~min}$. Protein concentrations of the extracts were determined using BCA (bicinchoninic acid) reagent (Thermo Scientific, Rockford, USA). Equal amounts of protein extracts (50 $\mu \mathrm{g}$ per lane) were separated by SDS-PAGE (sodium dodecyl sulfate-polyacrylamide gel electrophoresis) with $10 \%$ polyacrylamide gels (Rotiphorese-Gel 30, Roth, Karlsruhe, Germany) and transferred onto PVDF membranes (Poly Screen PVDF Transfer Membrane, Perkin Elmer, Rodgau, Germany) by semi-dry blotting. Membranes were blocked according to instruction manual of antibody manufacturer for one hour. Next, membranes were incubated with primary antibodies in blocking solution (tris buffered saline (TBS), 0.1\% Tween 20 and $5 \%$ non-fat milk) at $4^{\circ} \mathrm{C}$ overnight. The antibodies against CaSR (novus biologicals), phosphoAKT (Ser473, Cell Signaling, Boston, USA), phosphoERK1/2 (ERK1 Thr202/Tyr204, ERK2 Tyr185/Tyr187, R\&D Systems, Minneapolis, USA), phospho-JNK (Y185), phospho-SHC (Y239/240) and phospho-P90RSK (S380), all from Cell Signalling, Boston, USA, were diluted 
1:1000. After washing the membrane three times it was incubated with HRP-conjugated secondary antibodies (DAKO) at a dilution of 1:1000 for one hour at room temperature. Antigens were visualized by an enhanced chemiluminescence solution (ECL, Perkin Elmer Life Sciences, Waltham, USA) using a chemiluminescence imaging system (Fluorchem E (Biozym)). For quantification a computer-based pixel counting system was used (AlphaView, Protein Simple), subtracting the background from the visual band. These values were normalized to Coomassie stained amounts.

\section{Tumor xenografts}

All animal studies were performed in accordance of the guidelines of the Canadian Council on Animal Care with institutional certifications (University of British Columbia). Under gas anesthesia, $5 \times 10^{6} 768-\mathrm{O}-\mathrm{CaSR}$ and 768-O-vector cells were injected into the left ventricle of 8- to 10-week-old nude mice via ultrasound guidance (small animal imaging system Vevo 770, FUJIFILM VisualSonics). Each cell line was implanted into 15 mice. Four mice in the CaSR and two mice in the vector group had to be sacrificed immediately after injection. The remaining mice were monitored twice weekly for weight and daily for appearance. All animals were euthanized according to the animal ethics protocol at the completion of the study (day 69).

\section{Imaging}

The establishment of metastases was followed by bioluminescence imaging (IVIS ${ }^{\circledR}$ Lumina; PerkinElmer). Mice were examined by IVIS weekly for 2 weeks and afterwards twice weekly in 360 degrees, by four consecutive images and rotation of the animal that each side faced towards the sensor in one image to reduce confounding by absorption of bioluminescence by tissue covering the metastases. In addition, before euthanasia the animals were injected with luciferin and after confirming bioluminescence activity, rapidly dissected according to our template. The number of hotspots shown in the IVIS images pre and post-mortem showed a complete correlation. Histologic images of each suspected metastasis were performed to identify the exact location.

\section{MRI Imaging}

MRI experiments were completed using a 7 Tesla Bruker Biospec 70/30 scanner to evaluate the accuracy of the IVIS imaging. A volume coil with $70 \mathrm{~mm}$ i.d. was used for signal transmission and reception. RARE T2-weighted scans were acquired and used to identify areas with possible bone metastasis, which would appear hyperintense $(\mathrm{TE}=46.1 \mathrm{~ms}, \mathrm{RARE}$ factor $=8$, $\mathrm{FOV}=9 \times 4 \mathrm{~cm}, 256 \times 256$, slice thickness $=1.5 \mathrm{~mm})$.
Diffusion images were then acquired in these regions using either DTI-EPI or Spin-Echo DTI with a field-ofview of $4 \mathrm{~cm} \times 4 \mathrm{~cm}$, a matrix size of $128 \times 128$, a slice thickness of $1.5 \mathrm{~mm}$, and one diffusion direction. DTIEPI was taken using 8-shots, an echo time of $32.84 \mathrm{~ms}$, a $3000 \mathrm{~ms}$ repetition time, and 6 averages. Spin-Echo DTI had an echo time of $21.337 \mathrm{~ms}$, a repetition time of $1200 \mathrm{~ms}$ and 1 average. We could demonstrate that only metastasis with a bioluminescent response of at least $10^{6}$ photons/sec could be detected in the MRI. MRI was performed on two animals per group. Therefore, tumors with a bioluminescence of at least $10^{6}$ photons/sec were classified as relevant metastasis. We did not find any other metastasis on MRI that were not seen on IVIS imaging.

\section{Tissue extraction}

To locate metastasis in our mouse model, animals were injected with luciferin $10 \mathrm{~min}$ before euthanasia and 4 IVIS images were taken to screen for metastasis. After euthanasia, the skin of the mice was removed and each animal was dissected using a template. Extremities, lower and upper spine, left part of head, right part of head, tail, thorax, pelvic area and every organ were imaged with IVIS, separated from each other in 6-well-plates. Areas with increased bioluminescence were further dissected to isolate the metastasis from surrounding tissue. Samples were then stored in $4 \%$ paraformaldehyde for 24 hours at $4^{\circ} \mathrm{C}$ and switched to $70 \%$ Ethanol thereafter.

\section{Histology}

Before immunohistochemical staining decalcification was performed. Tissues were left in 0.5 molar EDTA on the shaker to facilitate fluid infiltration for a total of 7 days.. EDTA solution was refreshed every 2-3 days. Once decalcification was complete, tissue was washed with distilled water then store in $70 \%$ ethanol prior to tissue processing. Immunohistochemical staining was performed on formalin-fixed, paraffin-embedded $5 \mu \mathrm{m}$ tumor sections using the appropriate primary antibody (haematoxylin and eosin)) and the Ventana autostainer Discover XT (Ventana Medical Systems).

\section{Statistical analysis}

Differences between the two groups were compared using Student $t$ test and Mann-Whitney $U$ test. All statistical calculations were performed using IBM-SPSS 24.0 software and Excel 2010 and $P$ values $<0.05$ were considered significant.

\section{Abbreviations}

AKT: AKT8 virus oncogene cellular homolog; $\mathrm{Ca}^{2+}$ : calcium; CaSR: calcium-sensing receptor; ccRCC: clear cell RCC; ECM: extracellular matrix; ERK: 
extracellular signal-regulated kinase; FAK: focal adhesion kinase; JNK: c-Jun N-terminal kinase; MAPK: mitogen activated protein kinase; PI3K: phosphatidylinositol-4,5bisphosphate 3-kinase; PSA: prostate specific antigen; RANK: receptor activator of NF- $\kappa$ B; RANKL: RANK ligand; RCC: renal cell carcinoma; SHC: SRC homology 2 containing-protein.

\section{Author contributions}

Sebastian Frees: Protocol/project development, Data collection or management, Data analysis, Manuscript writing/editing; Ines Breuksch: Protocol/ project development, Data collection or management, Data analysis, Manuscript writing/editing; Tobias Haber: Protocol/project development, Data collection or management, Data analysis; Heide-Katharina Bauer: Data analysis, Manuscript editing; Claudia ChavezMunoz: Protocol/project development, Data collection or management, Data analysis, Manuscript writing/editing; Peter Raven: Data collection or management; Igor Moskalev: Data collection or management, Data analysis; Ninadh D'Costa: Data collection or management; Tan Zeng: Data collection or management; Mads Daugaard: Protocol/project development; Joachim W. Thüroff: Protocol/project development; Axel Haferkamp: Manuscript writing/editing; Dirk Prawitt: Protocol/project development, Data analysis, Manuscript editing; Alan So: Protocol/project development, Data analysis, Manuscript writing/editing; Walburgis Brenner: Protocol/project development, Data analysis, Manuscript writing/editing.

\section{CONFLICTS OF INTEREST}

No conflict of interest.

\section{FUNDING}

Parts of this work were funded by the Wilhelm Sander Foundation. Dr. Sebastian Frees held a scholarship from the Deutsche Forschungsgemeinschaft (DFG).

\section{REFERENCES}

1. Society AC. Cancer Facts \& Figures 2016. (Atlanta: American Cancer Society). 2016.

2. Chow WH, Devesa SS, Warren JL, Fraumeni JF Jr. Rising incidence of renal cell cancer in the United States. JAMA. 1999; 281:1628-31.

3. Decastro GJ, McKiernan JM. Epidemiology, clinical staging, and presentation of renal cell carcinoma. Urol Clin North Am. 2008; 35:581-92. https://doi.org/10.1016/j. ucl.2008.07.005.
4. Sun M, Choueiri TK. Kidney cancer: Recurrence in renal cell carcinoma: the work is not done. Nat Rev Urol. 2016; 13:246-7. https://doi.org/10.1038/nrurol.2016.57.

5. Mikami S, Oya M, Mizuno R, Kosaka T, Katsube KI, Okada Y. Invasion and metastasis of renal cell carcinoma. Medical molecular morphology. 2014; 47:63-7.

6. Hess KR, Varadhachary GR, Taylor SH, Wei W, Raber MN, Lenzi R, Abbruzzese JL. Metastatic patterns in adenocarcinoma. Cancer. 2006; 106:1624-33.

7. Zekri J, Ahmed N, Coleman RE, Hancock BW. The skeletal metastatic complications of renal cell carcinoma. Int $\mathrm{J}$ Oncol. 2001; 19:379-82.

8. Riccardi D, Brown EM. Physiology and pathophysiology of the calcium-sensing receptor in the kidney. Am J Physiol Renal Physiol. 2010; 298:F485-99. https://doi.org/10.1152/ ajprenal.00608.2009.

9. Atchison DK, Beierwaltes WH. The influence of extracellular and intracellular calcium on the secretion of renin. Pflugers Arch. 2013; 465:59-69. https://doi. org/10.1007/s00424-012-1107-x.

10. Ward DT, Riccardi D. New concepts in calcium-sensing receptor pharmacology and signalling. Br J Pharmacol. 2012; 165:35-48. https://doi.org/10.1111/j.1476-5381.2011.01511.x.

11. Diez-Fraile A, Lammens T, Benoit Y, D’Herde KG. The calcium-sensing receptor as a regulator of cellular fate in normal and pathological conditions. Curr Mol Med. 2013; 13:282-95.

12. Brennan SC, Conigrave AD. Regulation of cellular signal transduction pathways by the extracellular calcium-sensing receptor. Curr Pharm Biotechnol. 2009; 10:270-81.

13. Mihai R, Stevens J, McKinney C, Ibrahim NB. Expression of the calcium receptor in human breast cancer--a potential new marker predicting the risk of bone metastases. Eur $\mathrm{J}$ Surg Oncol. 2006; 32:511-5. https://doi.org/10.1016/j. ejso.2006.02.009.

14. Feng J, Xu X, Li B, Brown E, Farris AB, Sun SY, Yang JJ. Prostate cancer metastatic to bone has higher expression of the calcium-sensing receptor (CaSR) than primary prostate cancer. Receptors Clin Investig. 2014; 1. https:// doi.org/10.14800/rci.270.

15. Joeckel E, Haber T, Prawitt D, Junker K, Hampel C, Thuroff JW, Roos FC, Brenner W. High calcium concentration in bones promotes bone metastasis in renal cell carcinomas expressing calcium-sensing receptor. Mol Cancer. 2014; 13 : 42. https://doi.org/10.1186/1476-4598-13-42.

16. Yin JJ, Pollock CB, Kelly K. Mechanisms of cancer metastasis to the bone. Cell Res. 2005; 15:57-62. https:// doi.org/10.1038/sj.cr.7290266.

17. Neudert M, Fischer C, Krempien B, Bauss F, Seibel MJ. Site-specific human breast cancer (MDA-MB-231) metastases in nude rats: model characterisation and in vivo 
effects of ibandronate on tumour growth. Int $\mathrm{J}$ Cancer. 2003; 107:468-77. https://doi.org/10.1002/ijc.11397.

18. Omae K, Tsujimoto Y, Honda M, Kondo T, Tanabe K, Fukuhara S, Furukawa TA. Comparative efficacy and safety of bone-modifying agents for the treatment of bone metastases in patients with advanced renal cell carcinoma: a systematic review and meta-analysis. Oncotarget. 2017; 8:68890-8. https://doi.org/10.18632/oncotarget.20323.

19. Brown EM, Gamba G, Riccardi D, Lombardi M, Butters R, Kifor O, Sun A, Hediger MA, Lytton J, Hebert SC. Cloning and characterization of an extracellular $\mathrm{Ca}(2+)$-sensing receptor from bovine parathyroid. Nature. 1993; 366:57580. https://doi.org/10.1038/366575a0.

20. Liao J, Schneider A, Datta NS, McCauley LK. Extracellular calcium as a candidate mediator of prostate cancer skeletal metastasis. Cancer Res. 2006; 66:9065-73. https://doi. org/10.1158/0008-5472.CAN-06-0317.

21. Saidak Z, Mentaverri R, Brown EM. The role of the calcium-sensing receptor in the development and progression of cancer. Endocr Rev. 2009; 30:178-95. https://doi.org/10.1210/er.2008-0041.

22. Breuksch I, Weinert M, Brenner W. The role of extracellular calcium in bone metastasis. J Bone Oncol. 2016; 5:143-5. https://doi.org/10.1016/j.jbo.2016.06.004.

23. Chirgwin JM, Guise TA. Molecular mechanisms of tumor-bone interactions in osteolytic metastases. Crit Rev Eukaryot Gene Expr. 2000; 10:159-78.

24. Yasuda H, Shima N, Nakagawa N, Yamaguchi K, Kinosaki M, Goto M, Mochizuki SI, Tsuda E, Morinaga T, Udagawa N, Takahashi N, Suda T, Higashio K. A novel molecular mechanism modulating osteoclast differentiation and function. Bone. 1999; 25:109-13.

25. Boudot C, Henaut L, Thiem U, Geraci S, Galante M, Saldanha P, Saidak Z, Six I, Clezardin P, Kamel S, Mentaverri R. Overexpression of a functional calciumsensing receptor dramatically increases osteolytic potential of MDA-MB-231 cells in a mouse model of bone metastasis through epiregulin-mediated osteoprotegerin downregulation. Oncotarget. 2017; 8:56460-72. https://doi. org/10.18632/oncotarget.16999.

26. Guise TA, Yin JJ, Mohammad KS. Role of endothelin-1 in osteoblastic bone metastases. Cancer. 2003; 97:779-84. https://doi.org/10.1002/cncr.11129.

27. Ode A, Duda GN, Glaeser JD, Matziolis G, Frauenschuh S, Perka C, Wilson CJ, Kasper G. Toward biomimetic materials in bone regeneration: functional behavior of mesenchymal stem cells on a broad spectrum of extracellular matrix components. Journal of Biomedical Materials Research Part A. 2010; 95:1114-24.

28. Kopp HG, Avecilla ST, Hooper AT, Rafii S. The bone marrow vascular niche: home of HSC differentiation and mobilization. Physiology. 2005; 20:349-56.

29. Tharmalingam S, Daulat AM, Antflick JE, Ahmed SM, Nemeth EF, Angers S, Conigrave AD, Hampson DR.
Calcium-sensing receptor modulates cell adhesion and migration via integrins. J Biol Chem. 2011; 286:40922-33. https://doi.org/10.1074/jbc.M111.265454.

30. Saidak Z, Boudot C, Abdoune R, Petit L, Brazier M, Mentaverri R, Kamel S. Extracellular calcium promotes the migration of breast cancer cells through the activation of the calcium sensing receptor. Exp Cell Res. 2009; 315:207280. https://doi.org/10.1016/j.yexcr.2009.03.003.

31. Hills CE, Younis MY, Bennett J, Siamantouras E, Liu KK, Squires PE. Calcium-sensing receptor activation increases cell-cell adhesion and $\beta$-cell function. Cellular Physiology and Biochemistry. 2012; 30:575-86.

32. Li GW, Xing WJ, Bai SZ, Hao JH, Guo J, Li HZ, Li HX, Zhang WH, Yang BF, Wu LY. The Calcium-Sensing Receptor Mediates Hypoxia-Induced Proliferation of Rat Pulmonary Artery Smooth Muscle Cells Through MEK1/ERK1, 2 and PI3K Pathways. Basic \& clinical pharmacology \& toxicology. 2011; 108:185-93.

33. Fidler IJ. The pathogenesis of cancer metastasis: the'seed and soil'hypothesis revisited. Nature Reviews Cancer. 2003; 3:453-9.

34. Wetterwald A, van der Pluijm G, Que I, Sijmons B, Buijs J, Karperien M, Löwik CW, Gautschi E, Thalmann GN, Cecchini MG. Optical Imaging of Cancer Metastasis to Bone Marrow: A Mouse Model of Minimal Residual Disease. The American Journal of Pathology. 2002; 160:1143-53. https:// doi.org/10.1016/S0002-9440(10)64934-6.

35. Jensen AA, Brauner-Osborne H. Allosteric modulation of the calcium-sensing receptor. Current neuropharmacology. 2007; 5:180-6.

36. Marquis RW, Lago AM, Callahan JF, Rahman A, Dong X, Stroup GB, Hoffman S, Gowen M, DelMar EG, Van Wagenen BC, Logan S, Shimizu S, Fox J, et al. Antagonists of the calcium receptor. 2. Amino alcohol-based parathyroid hormone secretagogues. J Med Chem. 2009; 52:6599-605. https://doi.org/10.1021/jm900563e.

37. Nemeth EF, Delmar EG, Heaton WL, Miller MA, Lambert LD, Conklin RL, Gowen M, Gleason JG, Bhatnagar PK, Fox J. Calcilytic compounds: potent and selective $\mathrm{Ca} 2+$ receptor antagonists that stimulate secretion of parathyroid hormone. J Pharmacol Exp Ther. 2001; 299:323-31.

38. Gorvin CM, Hannan FM, Howles SA, Babinsky VN, Piret SE, Rogers A, Freidin AJ, Stewart M, Paudyal A, Hough TA, Nesbit MA, Wells S, Vincent TL, et al. Galpha11 mutation in mice causes hypocalcemia rectifiable by calcilytic therapy. JCI Insight. 2017; 2:e91103. https://doi. org/10.1172/jci.insight.91103.

39. Canalis E. Novel treatments for osteoporosis. J Clin Invest. 2000; 106:177-9.

40. Hannan FM, Walls GV, Babinsky VN, Nesbit MA, Kallay E, Hough TA, Fraser WD, Cox RD, Hu J, Spiegel AM, Thakker RV. The Calcilytic Agent NPS 2143 Rectifies Hypocalcemia in a Mouse Model With an Activating Calcium-Sensing Receptor (CaSR) Mutation: Relevance 
to Autosomal Dominant Hypocalcemia Type 1 (ADH1). Endocrinology. 2015; 156:3114-21. https://doi.org/10.1210/ en.2015-1269.

41. Rybczynska A, Marchwinska A, Dys A, Boblewski K, Lehmann A, Lewko B. Activity of the calcium-sensing receptor influences blood glucose and insulin levels in rats. Pharmacol Rep. 2017; 69:709-13. https://doi.org/10.1016/j. pharep.2017.01.034.

42. Hadaschik BA, Black PC, Sea JC, Metwalli AR, Fazli L, Dinney CP, Gleave ME, So AI. A validated mouse model for orthotopic bladder cancer using transurethral tumour inoculation and bioluminescence imaging. BJU Int. 2007; 100:1377-84. https://doi. org/10.1111/j.1464-410X.2007.07165.X.

43. Haber T, Jockel E, Roos FC, Junker K, Prawitt D, Hampel C, Thuroff JW, Brenner W, German Renal Cell Tumor Network. Bone Metastasis in Renal Cell Carcinoma is Preprogrammed in the Primary Tumor and Caused by AKT and Integrin alpha5 Signaling. J Urol. 2015; 194:539-46. https://doi.org/10.1016/j.juro.2015.01.079.

44. Schneider E, Keppler R, Prawitt D, Steinwender C, Roos FC, Thuroff JW, Lausch E, Brenner W. Migration of renal tumor cells depends on dephosphorylation of Shc by PTEN.
Int J Oncol. 2011; 38:823-31. https://doi.org/10.3892/ ijo.2010.893.

45. Peacock M. Hypercalcaemia and calcium homeostasis. Metabolic Bone Disease and Related Research. 1980; 2:143-50. https://doi.org/10.1016/0221-8747(80)90021-1.

46. Breuksch I, Prosinger F, Baehr F, Engelhardt F, Bauer H, Thueroff J, Heimes A, Hasenburg A, Prawitt D, Brenner $\mathrm{W}$. Integrin $\alpha 5$ triggers the metastatic potential in renal cell carcinoma. Oncotarget. 2017; 8:107530-107542. https:// doi.org/10.18632/oncotarget.22501.

47. Brenner W, Beitz S, Schneider E, Benzing F, Unger RE, Roos FC, Thuroff JW, Hampel C. Adhesion of renal carcinoma cells to endothelial cells depends on PKCmu. BMC Cancer. 2010; 10:183. https://doi. org/10.1186/1471-2407-10-183.

48. Ishibashi K, Haber T, Breuksch I, Gebhard S, Sugino T, Kubo H, Hata J, Koguchi T, Yabe M, Kataoka M, Ogawa $\mathrm{S}$, Hiraki H, Yanagida T, et al. Overriding TKI resistance of renal cell carcinoma by combination therapy with IL-6 receptor blockade. Oncotarget. 2017; 8:55230-45. https:// doi.org/10.18632/oncotarget.19420. 